\title{
Investigation of Ram Sperm Acrosome Integrity in Relation with Seminal Plasma Homocysteine and Nesfatin-1 Levels
}

\author{
Caner ÖZTÜRK'*, Şükrü GÜNGÖR ${ }^{2}$, Muhammed Enes İNANÇ², Neşe Hayat AKSOY³ \\ 1 Aksaray University, Faculty of Veterinary Medicine, Department of Reproduction and Artificial Insemination, Aksaray, Turkey \\ ${ }^{2}$ Mehmet Akif Ersoy University, Faculty of Veterinary Medicine, Department of Reproduction and Artificial Insemination, Burdur, Turkey \\ ${ }^{3}$ Aksaray University, Faculty of Veterinary Medicine, Department of Biochemistry, Aksaray, Turkey
}

\begin{abstract}
This study aimed to investigate the relationship between homocysteine, nesfatin-1 levels with acrosome integrity. Ejaculates were collected from six adult rams via artificial vagina, divided into five groups and diluted at $37^{\circ} \mathrm{C}$. The extenders, which contained cholesterol loaded cyclodextrin (CLC) 1.5 and $2.5 \mathrm{mg}$, cholesterol loaded 7dehydrocholesterol (7-DCLC) 1.5 and $2.5 \mathrm{mg}$ or no additive (control), were used for sperm dilution. Semen samples of all groups were cooled at $5^{\circ} \mathrm{C}$ and then frozen in liquid nitrogen vapor $\left(-110 \sim-120^{\circ} \mathrm{C}\right)$. Semen samples stored in liquid nitrogen then were thawed at $38^{\circ} \mathrm{C}$ for 30 seconds prior to examination. Acrosome integrity was examined with FITC-PNA staining. Homocysteine (HCY) and nesfatin-1 assays were performed with ELISA method. In the CLC 1.5 and $2.5 \mathrm{mg}$ groups homocysteine levels were lower $(0.67 \pm 0.11 ; 0.61 \pm 0.26)$ compared to control group $(1.36 \pm 0.9)(p<0.05)$. No statistical differences were observed between groups in nesfatin-1 levels $(p>0.05)$. In CLC $2.5 \mathrm{mg}$, the values of spermatozoa with intact acrosome membrane $(65.88 \pm 2.84)$ were higher $(\mathrm{p}<0.05)$ than in control group (52.38 \pm 2.97$)$. Sperm acrosome integrity was negatively correlated with HCY level $(\mathrm{r}=-, 630)$ and positive correlated with nesfatin-1 levels $(r=, 460)$ in thawed ram sperm. In conclusion, CLC has a cryoprotective effect on acrosome integrity and found to have beneficial effects on HCY level.
\end{abstract}

Keywords: Acrosome integrity, Cyclodextrin, 7-dehydrocholesterol, Homocysteine, Nesfatin-1

\section{Koç Sperma Akrozom Bütünlüğünün Seminal Plazma Homosistein ve Nesfatin-1 Düzeyleri ile İlişkili Olarak İncelenmesi}

\section{ÖZ}

Bu çalışmada homosistein, nesfatin-1 düzeyleri ile akrozom bütünlüğü arasındaki ilişkinin araştırılması amaçlanmıştır. Ejakülatlar, suni vajen yöntemiyle altı yetişkin koçtan alındı ve toplanan ejakülatlar beş gruba bölünerek $37{ }^{\circ} \mathrm{C}^{\prime}$ de sulandırıldı. Sperma sulandırılmasında kolesterol yüklü siklodekstrin (CLC) 1.5 ve $2.5 \mathrm{mg}$, kolesterol yüklü 7-dehidrokolesterol (7-DCLC) $1.5 \mathrm{ve} 2.5 \mathrm{mg}$ içeren veya katk1 maddesi içermeyen (kontrol) sulandırıcılar kullanıldı. Tüm gruplardaki sperma örnekleri $5^{\circ} \mathrm{C}^{\prime}$ de soğutulduktan sonra sıvı nitrojen buharında ($110 \sim-120^{\circ} \mathrm{C}$ ) donduruldu. Sıvı nitrojen içinde saklanan sperma örnekleri incelenmek için $38^{\circ} \mathrm{C}$ ve 30 saniyede çözdürüldü. Akrozom bütünlügü, FITC-PNA boyama ile incelendi. Homosistein (HCY) ve nesfatin-1 testleri ELISA yöntemi ile yapıldı. CLC 1.5 ve $2.5 \mathrm{mg}$ gruplarında homosistein seviyeleri kontrol grubuna (1.36 \pm 0.9$)$ göre daha düşük bulundu $(0.67 \pm 0.11,0.61 \pm 0.26)(\mathrm{p}<0.05)$. Nesfatin-1 düzeylerinde gruplar arasında istatistiksel olarak fark gözlenmedi ( $p>0.05$ ). $2.5 \mathrm{mg}$ CLC'de akrozom bütünlügü bozulmamış sperma hücrelerinin oranları (65.88 \pm 2.84$)$ kontrol grubuna $(52.38 \pm 2.97)$ göre daha yüksek bulundu $(\mathrm{p}<0.05)$. Sperma akrozom bütünlüğü, çözüm sonu koç spermasında HCY seviyesi $(r=-, 630)$ ile negatif, nesfatin-1 seviyeleri $(r=, 460)$ ile pozitif korelasyon gösterdi. Sonuç olarak, CLC'nin akrozom bütünlügü üzerinde kriyoprotektif bir etki gösterdiği ve HCY seviyesi üzerinde faydalı olduğu belirlenmiştir.

Anahtar Kelimeler: Akrozom bütünlüğü, Siklodekstrin, 7-dehidrokolesterol, Homosistein, Nesfatin-1

To cite this article: Örtürk. C. Güngör S. Inanç M.E. Aksoy N.H. Investigation of Ram Sperm Acrosome Integrity in Relation with Seminal Plasma Homocysteine and Nesfatin-1 Levels. Kocatepe Vet J. (2021):14(1):123-128

Submission: 27.11.2020 Accepted: 27.01.2021 Published Online: 26.02..2021

ORCID ID; CÖ: 0000-0003-0566-0684 ŞG: 0000-0003-3460-522X MEİ: 0000-0001-6954-6309NHA: 0000-0001-9039-555X

*Corresponding author e-mail: canerozturkvt@gmail.com 


\section{INTRODUCTION}

Artificial insemination plays an important role in sheep breeding. Breeds with superior genetic characteristics can be grown with the application of this tool (Maxwell and Watson 1996). The lipid composition of plasma membrane of ram sperm is different compared to the other species (Yurdakök et al. 2015). Consequently, ram sperm cannot be frozen successfully as bull sperm (Salamon and Maxwell 2000). The lipid components of the spermatozoa membranes affect the ability of sperm to respond on freezing, as well as the ability of sperm to provide the acrosome reaction (Moore et al. 2005). The plasma membrane and outer acrosomal membrane of the sperm cell are very sensitive to the freeze-thaw process. These structures, consisting of thermodynamic phospholipids $(65-70 \%)$ and pass irreversibly from the liquid phase to the gel phase when the membranes cool down (Watson 2000). The cholesterol-phospholipid ratio in the sperm plasma membranes changes during the freezing of the sperm, resulting in reduced fertility (Khan et al. 2017).

Cyclodextrin (CLC) is cyclic heptasaccharides consisting of $\beta-(1-4)$ water-soluble glycopyranose units. CLC is used to add cholesterol to the cell membrane or to extract from the cell membrane (Purdy and Graham 2004). CLC is cholesterol-like hydrophobic compounds and carry the cholesterol of the cell plasma membrane into the hydrophobic region (Zidovetzki and Levitan 2007). When CLC is used in sperm cells, it ensures the removal of cholesterol that causes capacitation (Mocé et al. 2010). Researchers have demonstrated the ability to cholesterol loaded CLC in different species to increase sperm cryoprotection in stallion (Blommaert et al. 2016), ram (Naseer et al. 2015) and dog (Khan et al. 2017). Cholesterol is an important structural component of the membrane and takes part in the regulation of membrane function (Yeagle 1985). Cholesterol has many effects on the plasma membrane property. While reducing membrane permeability and phase changes, it provides a suitable environment for proteins and it is also a membrane antioxidant (Aksoy et al. 2010; Mocé et al. 2010). Cholesterol provides the transition temperature of the membranes and keeps them liquid, this feature allows it to reduce membrane damage (Glazar et al. 2009).

Homocysteine (HCY) is an amino acid produced by intracellular demethylation of methionine in methylation processes. The high level of HCY in the cell reveals its pathological effects by increasing oxidative stress (Voutilainen et al. 1999). Defective methylation, activation of apoptosis, induction of oxidative stress, altered nitric oxide bioavailability and increased inflammatory cytokine expression are molecular mechanisms of cellular dysfunction caused by HCY (Forges et al. 2007). High HCY concentration, abnormal spermatogenesis and infertility were found to coexist in male animals (Kelly et al. 2005)

Nesfatin-1 (N1) is an anorexigenic peptide involved in nutrition and metabolic regulation. It is reported that $\mathrm{N} 1$ is found not only in the brain, but also in peripheral organs such as digestive organs, heart and reproductive organs (Kim and Yang 2012). N1 is co-localized with gonadotropin releasing hormone, so it has been reported to be involved in gonadotropin release (García-Galiano et al. 2012). Studies have shown the important role of $\mathrm{N} 1$ in regulating male reproductive functions (Gao et al. 2016, Ranjan et al. 2019). N1 is localized with oxytocin (Maejima et al. 2009), a neurohormone associated with reproduction and erection. It is stated that the in vitro administration of $\mathrm{N} 1$ has a positive role in the regulation of reproduction in male rats (Gao et al. 2016).

In this study, we evaluated the effect of CLC and cholesterol loaded 7-dehydrocholesterol (7-DCLC) modification on the freezing of merino ram sperm by determining acrosome integrity and aimed to investigate its relationship between HCY and N1 levels.

\section{MATERIALS and METHODS}

\section{Animals and Semen Collection}

Sperm samples were collected from six adult merino rams with an artificial vagina. Semen collection procedures involving the use of animals were performed at Bahri Dagdas International Agricultural Research Institute. The study was approved by Institute Ethics Committee (No 2016/51).

\section{Semen Processing}

Tris Stock $(\mathrm{T})$ extender $(297.58 \mathrm{mM}$ tris, $82.66 \mathrm{mM}$ fructose, $96.32 \mathrm{mM}$ citric acid, 15\% egg yolk, $6 \%$ glycerol) was used as the main sperm extender in the study. Collected ejaculates (spermatozoa with $>80 \%$ motility and concentration higher than $2 \times 109$ spermatozoa $/ \mathrm{ml}$ ) after mixing, the ejaculate was divided into five aliquots and diluted at $37^{\circ} \mathrm{C}$ with base extenders containing CLC (1.5 and $2.5 \mathrm{mg}$ ), 7-DCLC $(1.5$ and $2.5 \mathrm{mg}$ ) and no additive) diluents (control). Semen samples were equilibrated at $5^{\circ} \mathrm{C}$ for 2 hours, and then loaded into $0.25 \mathrm{ml}$ straws. Samples were frozen $5 \mathrm{~cm}$ above liquid nitrogen vapor for 12 minutes. Then stored in liquid nitrogen $\left(-196^{\circ} \mathrm{C}\right)$. Straws were thawed after a one month later in a water bath at $38^{\circ} \mathrm{C}$ for 30 seconds and evaluated.

\section{Assessment of Sperm Acrosome Integrity}

Acrosome integrity was determined the method by Nagy et al. (2003). Thawed semen samples were diluted (1:3 with T) then $60 \mu \mathrm{l}$ were mixed with $10 \mu \mathrm{l}$ FITCPNA and $2.5 \mu$ PI. Samples were incubated in dark at $37^{\circ} \mathrm{C}$ for 20 minutes. Sperm acrosome integrity was determined using a fluorescence microscope (Carl Zeiss Axioscope 5 GmbH 07745, Germany). Sperm cells displaying bright green fluorescence were 
considered damaged, while those in red color in the acrosome cover that did not stain green fluorescence were considered intact.

Figure 1: Lectin/PI staining. Green headed shows damaged acrosome and red headed spermatozoon shows intact acrosome.

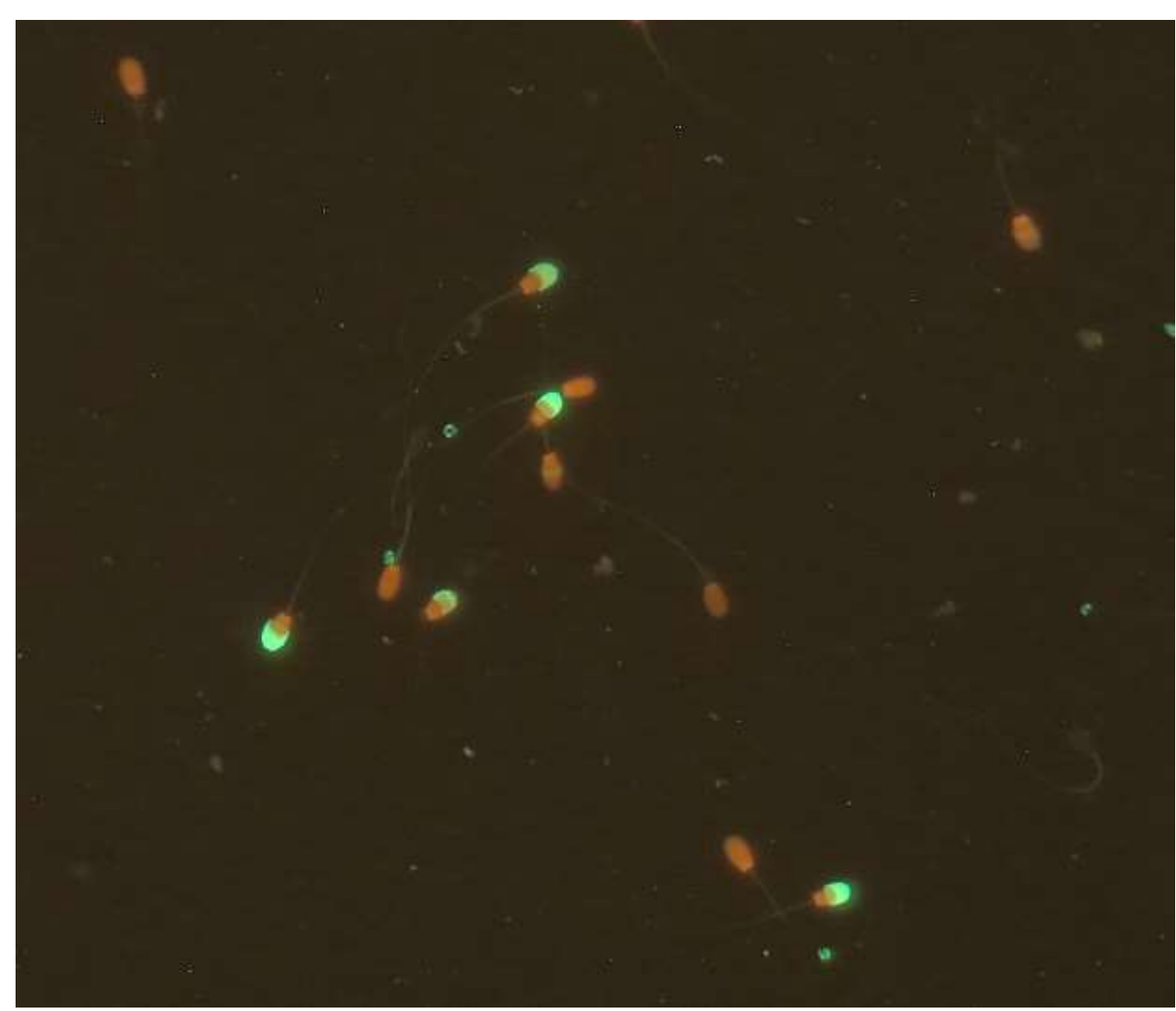

based on biotin double antibody technology (Shangai Sunred, Biological Tech., China). After the procedure

\section{Semen Preparation for Enzyme Assays}

To separate the cells from diluted seminal plasma, thawed semen samples were centrifuged at $4{ }^{\circ} \mathrm{C}$ and $800 \mathrm{rpm}$ for 15 minutes. All samples were washed twice with phosphate buffered saline (PBS, ph 7.2, tablet $/ 200 \mathrm{~mL}$ ) after centrifugation, the supernatant was removed then pellet was completed to $500 \mu \mathrm{l}$ with PBS. The prepared sperm suspension was sonicated with a probe for 10 seconds on ice.

\section{HCY Assays}

HCY peptides were blindly measured and read (450 $\mathrm{nm}$ ) ELISA plate reader (ELx800 Absorbance Microplate Reader) by the Biotin double-antibody technology (Shangai Sunred, Biological Tech., China). Homocysteine concentrations were calculated from standard curves.

\section{N1 Assays}

N1 measurement was performed by commercial enzyme-dependent immune sorbent assay (ELISA) of the ELISA kit, plates were read at $450 \mathrm{~nm}$ by the ELISA plate reader (ELx800 Absorbance Microplate Reader-Biotech).

\section{Statistical Analysis}

The normality and homogeneity of variances were checked with the help of the Shapiro-Wilk test. One Way Anova was used to evaluate sperm results and the results were expressed as mean \pm standard deviation. Analysis of variance, followed by Duncan's post hoc test to identify differences between groups. Differences with $\mathrm{p}<0.05$ values were considered statistically significant. SPSS 21 package program was used for analysis.

\section{RESULTS}

In 1.5 and $2.5 \mathrm{mg}$ CLC groups, the values of spermatozoa with intact acrosome membranes $(63.04 \% \pm 2.19 \%$ and $65.88 \% \pm 2.84 \%$ for 1.5 and 2.5 
mg CLC groups, respectively) were statistically different $(\mathrm{p}<0.05)$ compared to the control group (52.38 \pm 2.97 ; Table 1). No statistical differences $(p<0.05)$ were found between the two 7-DCLC groups and the control group. Levels of homocysteine were lower $(\mathrm{p}<0.05)$ in $1.5 \mathrm{mg}$ CLC $(0.67 \pm 0.11)$ and $2.5 \mathrm{mg}$ CLC $(0.61 \pm 0.26)$ compared to the control group
(1.36 \pm 0.9 ; Table 1). There was no statistical difference between the experimental groups about nesfatin-1 ( $>0.05$; Table 1). Furthermore, acrosome integrity of thawed ram semen was negatively correlated with $\operatorname{HCY}(\mathrm{r}=-, 630)$ and positively with N1 ( $\mathrm{r}=, 460$; Table 2).

Table 1. Mean ( \pm SEM) HCY, N1 levels and acrosome integrity in thawed ram semen.

\begin{tabular}{lccc}
\hline Groups & HCY $(\mu \mathrm{mol} / \mathrm{L})$ & $\mathrm{N} 1(\mathrm{ng} / \mathrm{mil})$ & Acrosome integrity $(\%)$ \\
\hline Control & $1.36 \pm 0.9^{\mathrm{a}}$ & $1.71 \pm 0.16$ & $52.38 \pm 2.97^{\mathrm{bc}}$ \\
CLC $1.5 \mathrm{mg}$ & $0.67 \pm 0.11^{\mathrm{b}}$ & $2.12 \pm 0.39$ & $63.04 \pm 2.19^{\mathrm{a}}$ \\
CLC 2.5 mg & $0.61 \pm 0.26^{\mathrm{b}}$ & $2.30 \pm 0.91$ & $65.88 \pm 2.84^{\mathrm{a}}$ \\
7-DCLC 1.5mg & $0.85 \pm 0.40^{\mathrm{ab}}$ & $1.78 \pm 0.14$ & $55.26 \pm 1.44^{\mathrm{b}}$ \\
7-DCLC 2.5 mg & $1.06 \pm 0.51^{\mathrm{a}}$ & $2.08 \pm 0.25$ & $51.76 \pm 0.69^{\mathrm{c}}$ \\
\hline P & $*$ & - & $*$
\end{tabular}

-: No significant difference.

$*(\mathrm{P}<0.05)$.

Table 2. Correlation results in thawed ram semen.

\begin{tabular}{|c|c|c|c|c|}
\hline & & Acrosome & & \\
\hline & & integrity & $\mathrm{HCY}$ & N1 \\
\hline Acrosome & Pearson Correlation & 1 &,$- 630^{* *}$ & ,460* \\
\hline integrity & Sig. (2-tailed) & &, 001 &, 021 \\
\hline & $\mathrm{N}$ & 25 & 25 & 25 \\
\hline $\mathrm{HCY}$ & Pearson Correlation &,$- 630^{* *}$ & 1 &,$- 408^{*}$ \\
\hline & Sig. (2-tailed) &, 001 & & 043 \\
\hline & $\mathrm{N}$ & 25 & 25 & 25 \\
\hline N1 & Pearson Correlation & $460^{*}$ &,$- 408^{*}$ & 1 \\
\hline & Sig. (2-tailed) & ,021 & ,043 & \\
\hline & $\mathrm{N}$ & 25 & 25 & 25 \\
\hline
\end{tabular}

**. Correlation is significant at the 0.01 level (2-tailed).

*. Correlation is significant at the 0.05 level (2-tailed).

\section{DISCUSSION}

The highest acrosome integrity rate was obtained in the group supplemented with CLC and a negative correlation was determined between acrosome reacted spermatozoa and the HCY level. It was seen that the determined negative correlation with HCY level could be directly related to sperm freezing. Cholesterol shows its effect on the cell membrane by protecting the antioxidative enzymes and preventing their spread to reactive oxidative species (López-Revuelta et al. 2007). This information supports our conclusions regarding the membrane integrity of cholesterol forms. In the cryopreservation of bull semen with CLC, it was provided a higher sperm membrane integrity after thawing (Purdy and Graham 2004). Positive result was obtained in the stallion semen as in the presented study (Moraes et al. 2015). Some researchers have found that the use of CLC conjugates on Piau swine (Pinho et al. 2016) and boar sperm (Tomás et al. 2011) has no protective effect on sperm parameters. This difference between the results of the studies is thought to be due to the dose difference. 
In CLC-treated sperm, high cholesterol concentrations before cooling and low cholesterol loss during cryopreservation can be achieved. However, the presence of excess cholesterol in the plasma membrane can adversely affect its capacitation and acrosome reaction (Purdy and Graham 2004). Supplementing the ram sperm diluent with cholesterol conjugates and 7-DCLC has been shown to increase membrane integrity (Inanc et al. 2018). Amorim et al. (2009) stated that cholesterol or pelargonic used in freezing bull semen is beneficial for thawed sperm membrane. In the presented study, the highest acrosome integrity values were reached in CLC groups. Although the effect of HCY on the male reproductive system is not fully explained, there is a positive correlation between the increase in seminal plasma HCY level and the decrease in spermatological parameters (Wallock et al. 2001). It is thought that $\mathrm{H}$ creates its pathological effect by inducing oxidative stress, which explains the etiology of the metabolite in defective sperm function. (Sibrian-Vazquez et al. 2010). HCY and glutathione (GSH) concentrations in the sperm cell were significantly lower in normozoospermic men and increased in those with pathological sperm parameters (Kralikova et al. 2017). These results are consistent with the negative correlation with the acrosome integrity we presented in our study. The increase in acrosome integrity observed in humans (Renard et al. 1996) and stallion (Trimeche et al. 1999) as a result of minimizing the level of lipid peroxidation and it is consistent with the decreased homocysteine level with increased acrosome integrity observed in this study.

$\mathrm{N} 1$ is the 82-amino acid hormone important in the regulation of reproduction derived from nucleobindin 2 precursor protein (Gao et al. 2016). It was localized in leydig cells in the testicles. N1 levels in testicles of adult rats were found to be higher compared to pubertal rats (García-Galiano et al. 2012). Tamer et al. (2018) showed that N1 protects spermatogenic cells by providing pro-inflammatory / anti-inflammatory cytokine balance in rats. N1 induced enhanced energy substrate transport may be responsible for promoting spermatogenesis. N1 significantly reduced oxidative stress by its stimulating effect on testicular activities. Thus, it is stated that nesfatin-1 positively affects spermatological parameters. Ranjan et al. (2019) reported that nesfatin-1 increased sperm count and fertility by increasing testicular function. In our study, it was positively correlated with acrosome integrity.

\section{CONCLUSIONS}

Adding CLC in semen extender had a protective effect on freezing ram semen. HCY and N1 levels were found to have an effect on semen freezing, and it was suggested that it would be useful to investigate spermatological parameters and HCY and N1 levels together in future studies.
Ethics Committee Information: The study was approved by Institute Ethics Committee (Bahri Dagdas International Agricultural Research Institute, No 2016/51).

Conflict of interest: The authors declare that there is no actual, potential or perceived conflict of interest for this article.

\section{REFERENCES}

Aksoy M, Akman O, Lehimcioğlu NC, Erdem H. Cholesterolloaded cyclodextrin enhances osmotic tolerance and inhibits the acrosome reaction in rabbit spermatozoa. Anim Reprod Sci. 2010; 120(1-4): 166-172.

Amorim EAM, Graham JK, Spizziri B, Meyers M, Torres CA. Effect of cholesterol or cholesteryl conjugates on the cryosurvival of bull sperm. Cryobiology. 2009; 58: 210214.

Blommaert D, Franck T, Donnay I, Lejeune JP, Detilleux J, Serteyn D. Substitution of egg yolk by a cyclodextrincholesterol complex allows a reduction of the glycerol concentration into the freezing medium of equine sperm. Cryobiology. 2016; 72: 27-32.

Forges T, Monnier-Barbarino P, Alberto, JM, GueantRodriguez RM, Daval JL, Gueant JL. Impact of folate and homocysteine metabolism on human reproductive health. Hum Reprod Update. 2007; 13(3): 225-238.

Gao X, Zhang K, Song M, Li X, Luo L, Tian Y, Zhang Y, Li Y, Zhang X, Ling Y, Fang F, Liu Y. Role of nesfatin-1 in the reproductive axis of male rat. Sci Rep. 2016; 6: e32877.

García-Galiano D, Pineda R, Ilhan T, Castellano JM, RuizPino F, Sánchez-Garrido M A Vazquez MJ, SangiaoAlvarellos S, Romero-Ruiz A, Pinilla L, Diéguez C, Gaytán F, Tena-Sempere M. Cellular distribution, regulated expression, and functional role of the anorexigenic peptide, NUCB2/nesfatin-1, in the testis. Endocrinology. 2012;153(4): 1959-1971.

Glazar AI, Mullen SF, Liu J, Benson JD, Critser JK, Squires EL, Graham JK. Osmotic tolerance limits and membranepermeability characteristics of stallion spermatozoa treated with cholesterol. Cryobiology. 2009; 59: 201-206.

Inanc ME, Uysal O, Ata A. Cryopreservation and evaluation of Akkaraman ram semen with 7-dehydrocholesterol. Vet J Ankara Univ. 2018; 65: 187-192.

Kelly TL, Neaga OR, Schwahn BC, Rozen R, Trasler JM. Infertility in 5,10- methylenetetrahydrofolate reductase (MTHFR)-deficient male mice is partially alleviated by lifetime dietary betaine supplementation. Biol Reprod. 2005; 72: 667-677.

Khan J, Tahir MZ, Khalid A, Sattar A and Ahmad N. Effect of cholesterol-loaded cyclodextrins on cryosurvival of dog spermatozoa. Reprod Domest Anim. 2017; 52: 265-268.

Kim J, Yang H. Nesfatin-1 as a new potent regulator in reproductive system. Dev Reprod 2012; 16(4): 253-264.

Kralikova M, Crha I, Huser M, Melounova J, Zakova J, Matejovicova M, Ventruba $\mathbf{P}$. The intracellular concentration of homocysteine and related thiols is negatively correlated to sperm quality after highly effective method of sperm lysis. Andrologia. 2017; 49(7): e12702.

López-Revuelta A, Sánchez-Gallego JI, García-Montero AC, Hernández-Hernández A, Sánchez-Yagüe J, Llanillo M. Membrane cholesterol in the regulation of aminophospholipid asymmetry and phagocytosis in 
oxidized erythrocytes. Free Radic Biol Med. 2007; 42(7): 1106-1118.

Maejima Y, Sedbazar U, Suyama S, Kohno D, Onaka T, Takano E, Yoshida N, Koike M, Uchiyama $Y$, Fujiwara K, Yashiro T, Horvath TL, Marcelo OD, Tanaka S, Dezaki K, Oh-I S, Hashimoto K, Shimizu H, Yada T. Nesfatin-1-regulated oxytocinergic signaling in the paraventricular nucleus causes anorexia through a leptin-independent melanocortin pathway. Cell Metab. 2009; 10(5): 355-365.

Maxwell WMC, Watson PF. Recent Progress in The Preservation of Ram Semen. Anim Reprod Sci. 1996; 42: 55-65.

Mocé E, Blanch E, Tomás C, Graham JK. Use of cholesterol in sperm cryopreservation: present moment and perspectives to future. Reprod Domest Anim. 2010; 45: 57-66.

Moore AI, Squires EL, Graham JK. Adding cholesterol to the stallion sperm plasma membrane improves cryosurvival. Cryobiology. 2005; 51: 241-249.

Moraes EA, Matos WCG, Graham JK, Ferrari Jr WD. Cholestanol-loaded-cyclodextrin improves the quality of stallion spermatozoa after cryopreservation. Anim Reprod Sci. 2015; 158: 19-24.

Nagy S, Jansen J, Topper EK, Gadella BM. A triple-stain flow cytometric method to assess plasma and acrosomemembrane integrity of cryopreserved bovine sperm immediately after thawing in presence of egg-yolk particles. Biol Reprod. 2003; 68: 1828-1835.

Naseer Z, Ahmad E, Aksoy M, Küçük N, Serin İ, Ceylan A, Boyacioğlu M, Kum C. Protective effect of cholesterolloaded cyclodextrin pretreatment against hydrogen peroxide induced oxidative damage in ram sperm. Cryobiology. 2015; 71: 18-23.

Pinho RO, Lima DM, Shiomi HH, Siqueira JB, Silveira CO, Faria VR, Lopes PS, Guimarães SE, Guimarães JD. Effect of cyclodextrin-loaded cholesterol conjugates on plasma membrane viability of Piau swine breed frozen/thawed spermatozoa. Cryobiology. 2016; 73: 1-6.

Purdy P, Graham J. Effect of cholesterol-loaded cyclodextrin on the cryosurvival of bull sperm. Cryobiology. 2004; 48: 3645.

Ranjan A, Choubey M, Yada T, Krishna A. Direct effects of neuropeptide nesfatin-1 on testicular spermatogenesis and steroidogenesis of the adult mice. Gen Comp Endocrinol. 2019; 271: 49-60.

Renard P, Grizard GG, Sion JF, Boucher B, Lannou DDL. Improvement of motility and fertilization potential of post thawhuman sperm using glutamine. Cryobiology. 1996; 33 : 311-319.

Salamon S, Maxwell WMC. Storage of ram semen. Anim Reprod Sci. 2000; 62(1-3): 77-111.

Sibrian-Vazquez M, Escobedo JO, Lim S, Samoei GK, Strongin RM. Homocystamides promote free-radical and oxidative damage to proteins. Proc Natl Acad Sci. (2010); 107(2): 551-554.

Tamer SA, Yildirim A, Köroğlu MK, Çevik Ö, Ercan F, Yeğen BÇ. Nesfatin-1 ameliorates testicular injury and supports gonadal function in rats induced with testis torsion. Peptides. 2018; 107: 1-9.

Tomás C, Blanch E, Hernandez M, Gil MA, Roca J, Vazquez JM, Martinez EA, Mocé E Treating boar sperm with cholesterol-loaded cyclodextrins widens the sperm osmotic tolerance limits and enhances the in vitro sperm fertilizing ability. Anim Reprod Sci. 2011; 129: 209-220.

Trimeche A, Yvon JM, Vidament M, Palmer E, Magistrini M. Effects of glutamine, proline, histidine and betaine on post-thaw motility of stallion spermatozoa. Theriogenology. 1999; 52: 181-191.
Voutilainen S, Morrow JD, Roberts LJ, Alfthan G, Alho H, Nyyssonen K, Salonen JT. Enhanced in vivo lipid peroxidation at elevated plasma total homocysteine levels. Arterioscler Thromb Vasc Biol. 1999; 19: 1263-1266.

Wallock LM, Tamura T, Mayr CA, Johnston KE, Ames BN, Jacob RA. Low seminal plasma folate concentrations are associated with low sperm density and count in male smokers and nonsmokers. Fertil Steril. 2001;75(2):252259.

Watson PF. The causes of reduced fertility with cryopreserved semen. Anim Reprod Sci. 2000; 60:481-492.

Yeagle PL. Cholesterol and the cell membrane. Biochim Biophys Acta Rev Biomembranes. 1985; 822: 267-287.

Yurdakök B, Tekin K, Daskin A, Filazi A. Effect of polychlorinated biphenyls 28,30 and 118 on bovine spermatozoa in vitro. Reprod Domest Anim. 2015; 50: 41 47.

Zidovetzki R, Levitan I. Use of cyclodextrins to manipulate plasma membrane cholesterol content: evidence, misconceptions and control strategies. Bioch Bioph Acta. 2007; 1768(6): 1311-1324. 